\title{
V6 - CARACTERIZAÇÃO FENOTÍPICA E MOLECULAR DOS VÍRUS QUIMÉRICOS FEBRE AMARELA / DENGUE CANDIDATOS A UMA VACINA TETRAVALENTE RECOMBINANTE CONTRA DENGUE
}

$\underline{\text { Luiz Gustavo Almeida Mendes }^{1}}$, Idevaldo Inácio Ferreira ${ }^{1}$, André Tavares da Silva Fernandes $^{1}$, Ana Paula Yorio ${ }^{1}$, Cristiane Pestana ${ }^{1}$, Márcia Archer da Motta ${ }^{1}$

1-Bio-Manguinhos, Fundação Oswaldo Cruz, Desenvolvimento Tecnológico, Rio de janeiro, Brasil.

Objetivo: Avaliar as características genéticas e biológicas de vírus quiméricos febre amarela/dengue, considerando que é um protótipo vacinal tetravalente contra a dengue.

Metodologia: Para a caracterização biológica avaliamos as curvas de crescimento viral pela infecção de monocamadas de células em frascos de $\mathrm{T}-175 \mathrm{~cm}^{2}$ e garrafas Cellfactory de duas, quatro e dez camadas tendo cada camada $632 \mathrm{~cm}^{2}$. Utilizamos 60.000 células $/ \mathrm{cm}^{2}$ e $24 \mathrm{hrs}$ após semeadura infectamos com moi de 0,002. Para caracterização genética fizemos a análise molecular através da estabilidade genética, onde culturas de células Vero foram inoculadas com os vírus quiméricos, oriundos da purificação viral, a fim de estabelecermos o perfil genético do vírus. Assim oito passagens sucessivas foram realizadas utilizando os clones virais de DEN1, DEN2, DEN3 e DEN4. A análise deste sequenciamento foi feito no DNAstar. Já que os nossos vírus possuem maquinaria replicativa de febre amarela (vírus neurotrópico) e proteínas de envelope e membrana do vírus dengue, realizamos um teste de neurovirulência dividido em dois experimentos com camundongos Swiss de três semanas de idade com input viral de $10^{3} \mathrm{PFU} / 30 \mu \mathrm{l}$ no primeiro experimento e no segundo com input viral não diluído e um segundo experimento com camundongos neonatos com input viral de $10^{3} \mathrm{PFU} / 20 \mu \mathrm{l}$. Seguimos com os testes em camundongo C57/b16, mas agora avaliando a proteção dos vírus quiméricos e seus derivados com input viral de $10^{4} \mathrm{PFU} / 100 \mu 1$.

Resultados: As construções dos vírus recombinantes YFV/DENV prM/E são viáveis, produzindo vírus que replicam eficientemente em garrafas estacionárias $\mathrm{T}-175 \mathrm{~cm}^{2} \mathrm{e}$ CellFatory, com propriedades de replicação similares aos vírus dengue selvagens parentais, sugerindo que a troca da prM/E de febre amarela pela mesma região de dengue é capaz de afetar esta característica fenotípica do vírus YFV17D. Após a etapa de 
purificação clonal os clones foram sequenciados e comparados com o lote de trabalho P2. Esta comparação revelou algumas alterações de aminoácido entre as passagens P2 e CP2 em todos os clones, exceto para os clones YFV/DENV4. Os clones CP2 foram propagados por mais oito vezes em célula Vero para determinar se os vírus eram geneticamente estáveis. Após as passagens observamos que muitas alterações foram de caráter adaptativo à célula Vero. Os resultados de neurovirulência não mostraram nenhuma diferença entre os dois testes com camundongos de três semanas, entretanto com os neonatos foram neurovirulentos. $\mathrm{O}$ teste de proteção demonstrou que o clone YFV/DENV2C alcançou 93\% de sobrevivência, YFV/DENV2A 81\% e YFV/DENV2B $75 \%$.

Conclusões: As quimeras alcançaram títulos satisfatórios quando produzidos em média escala. Apresentaram baixo número de mutações após as oito passagens. São menos neurovirulentos quando comparados a febre amarela e possuem níveis elevados de proteção. 